\title{
Pay rises eat into South African budget
}

[CAPE TOWN] At first glance, research appears to have fared well in the first budget of South Africa's new Finance Minister, Trevor Manuel, presented last month. Total allocations to the research councils increased by 15 per cent - from R993 million (US\$224 million) to R1,128 million well in excess of both the 6 per cent general budgetary increase and the country's inflation rate of 9 per cent.

But university researchers are unhappy that the Foundation for Research Development (FRD), the main funding agency for research, was awarded an increase of only 4 per cent in the funds it distributes to universities. Most of this money will go to salary increases to the staff employed by the research councils, whose research output, as measured by international citations, is notoriously low (see Nature 384, 11; 1997).

Some see an irony in the fact that the FRD was given top rating of all the research councils by the advisory committee that made recommendations to the government on how the science budget should be distributed. The committee's hearings were held in public for the first time last October, and its recommendations were published.

Rob Adam, deputy director-general at the Department of Arts, Culture, Science and Technology, says that the committee's recommendations were followed stringently. But he says that salary increases, over which the department has little influence, overshadowed reallocations made on the grounds of merit.

Adam adds that the reallocation of funds this year was "deliberately conservative", as the research councils are under review. There was little to be gained by making major reallocations before the process of rationalization that is expected to result from the review.

Dave Woods, vice-chancellor of Rhodes University, says that the budget will have the effect "of improving salaries of researchers employed by the councils at the expense of fostering competitive research". He adds that

\begin{tabular}{l} 
Allocations to South Africa's \\
science councils \\
\hline$\%$ increase 1996-97 to $1997-98$ \\
Council for Scientific and Industrial Research
\end{tabular}

\author{
IMAGE \\ UNAVAILABLE \\ FOR COPYRIGHT \\ REASONS
}

South Africa's Antarctic base took so long to finish that it sports the colours of the old national flag.

university salaries are lagging behind those in government and the research councils.

Total funding for tertiary education was increased by 11 per cent in the budget, with universities receiving 66 per cent of their entitlement under South Africa's complex funding formula (see Nature 384, 13; 1997). Although this is less than last year, when theywere awarded 68 per cent, it is more than the 60 per cent the government had proposed earlier.

Sibusiso Bengu, Minister of Education, has denied that this increase was agreed in response to widespread campus protests which accompanied the start of the academic year in February.
Another anomaly in the budget is the limited funding allocated to research in Antarctica. In January, South Africa opened a new base there at a cost of R80 million. But only R14 million has been allocated to the Antarctic research programme, of which R11 million will be spent on supplying and running the base. That leaves just R2.6 million for the Antarctic research programmes in geology, biology, oceanography and physics.

"We could do a lot more with a little more money," says Dave Walker of the University of Natal, who heads the physics programme that forms part of the Southern Hemisphere Auroral Radar Experiment.

Michaelcherry

\section{Developing world wired up to molecular data}

[LONDON] The Weizmann Institute in Israel launched on 31 March an expanded communications network to provide countries in eastern Europe and Asia with access to on-line molecular databanks and training in their use.

The International Center for Cooperation in BioInformatics (ICCB), which is sponsored by the United Nations Educational, Scientific and Cultural Organization (Unesco), will provide on-line data on genes and proteins, according to Luba Vikhanski, a spokesman for the Weizmann Institute.

"Computerized resources in molecular biology are now crucial for the progress of medicine, biotechnology and agriculture," says Vikhanski. Scientists in the United States, Japan and Western Europe have access to their own data networks, he says, but "their colleagues in most other regions lag far behind".

Scientists in Western Europe, for example, are connected to the European
Molecular Biology Network, EMBnet, which is based in the United Kingdom. Israel is connected to EMBnet and the Weizmann Institute hosts the Israeli node, providing access and training in bioinformatics to 250 research groups in Israel. "The ICCB will be the equivalent of EMBnet for the developing world," says Vikhanski.

Over the past three years, the institute has set up Unesco-sponsored activities in bioinformatics in Poland, Turkey and India, and most recently in China. These countries will now form the regional headquarters of the ICCB network, providing network access to their neighbours. Israel will serve as the central node, in addition to providing network access to the Middle East region.

Much of the discussion at a two-day inaugural meeting, which ended on 1 April, focused on the centre's future funding. The network cost US $\$ 256,000$ to set up, $\$ 200,000$ of which was provided by Unesco. The rest was provided by Israel's foreign ministry, the Weizmann Institute and industry. 